\title{
RELASI PENGUASAAN ELEMEN-ELEMEN MUSIKAL BERNYANYI DAN KONDISI STRES DALAM KONTEKS KOMPETISI BERNYANYI : STUDI KASUS PADUAN SUARA MAHASISWA
}

\author{
Tio Roby \\ tio.roby@yahoo.com
}

\begin{abstract}
Abstrak
Tujuan dari penelitian ini yaitu untuk mengetahui relasi antara penguasaan elemen-elemen musikal bernyanyi dan kondisi stres personal dalam konteks kompetisi/ kontestasi bernyanyi. Alasan mendasar penelitian ini adalah, adanya salah satu manfaat positif aktivitas bernyanyi yaitu untuk mereduksi kondisi stres personal yang sedang dialami (hasil dari penelitian-penelitian ilmiah, serta pendapat pakar yang relevan); sementara di sisi lain beberapa penelitian ilmiah telah menghasilkan kesimpulan, bahwa kondisi stres menjadi tercipta ketika seseorang harus berpenampilan di depan umum, misalkan aktivitas bernyanyi dalam konteks kompetisi. Penelitian kualitatif ini akan dilakukan melalui pendekatan studi kasus pada paduan suara mahasiswa; aktivitas bernyanyi dalam konteks kompetisi sebagai objek material, sedangkan psikologi sosial sebagai objek formalnya; perolehan data dilakukan dengan FGD; analisis data dilakukan melalui pengelompokan data/mencari pola data; teori musikal bernyanyi dan konsep stres akan digunakan untuk mengiterpretasikannya. Hasil dari penelitian ini yaitu, bahwa ketidaksiapan individu terkait penguasaan elemen-elemen musikal bernyanyi dalam konteks kompetisi bernyanyi akan menciptakan kondisi stres pada pelakunya/ individu tersebut.
\end{abstract}

Kata kunci : elemen-elemen musikal bernyanyi, kondisi stres, konteks kompetisi bernyanyi.

\begin{abstract}
The aim of this research is to know about the relation between mastery of singing musical elements and personal stress condition in singing competition context. The fundamental reason of this research is the fact that there's one of the benefits of singing activity, that is to reduce the personal stress condition being experienced (scientific reaserches's results, relevant expert opinion); in other side, many scientific researches have been concluded that stress condition will be produced while someone have to perform in public, as example is singing activity on competition context. This qualitative research used case study approach at college choir; singing activity on competition context as material object, social psychology as formal object; FGD was used-to get the datas; subdividing datas or look for the datas pattern was used-to analyse the datas; musical theory of singing and stress concept were used-to interpret the datas. The result of this research is, that individual's unpreparedness with mastery of singing musical elements on singing competition context will creates stress condition on doers.
\end{abstract}

Keywords: singing musical elements, stress condition, singing competition context.

\section{Pendahuluan}

Aktivitas bernyanyi merupakan salah satu perilaku musikal yang dapat teramati dalam kehidupan sehari-hari, melalui diri sendiri maupun orang lain yang melakukannya. Salah satu tujuan orang melakukan aktivitas bernyanyi yaitu, untuk mengurangi kondisi stres yang sedang dirasakan. Seperti pendapat Tanigawa (Profesor dari Ehime University Graduate School of Medicine, Jepang), yang mengatakan sembilan manfaat aktivitas 
bernyanyi melalui karaoke: menjadikan pernafasan lebih baik, merangsang aktivitas otak, melepaskan hormon bahagia, mengoksidasi darah, mengurangi stres, membangun kepercayaan diri, meningkatkan kreativitas, menciptakan suara yang bertenaga, serta meningkatkan ketajaman memori. Berdasarkan beberapa manfaat tersebut, maka secara umum efek positif aktivitas bernyanyi dapat dirasakan melalui fisik maupun psikis pelakunya.

Beberapa fakta relevan yang mendukung pernyataan bahwa aktivitas bernyanyi mampu mereduksi kondisi stres yaitu, penelitian-penelitian ilmiah seperti yang dilakukan oleh Matsumoto et al. (2016). Penelitian tersebut menghasilkan kesimpulan, bahwa responden yang melakukan aktivitas bernyanyi di tempat karaoke mengalami penurunan kondisi stres yang sedang dirasakan secara signifikan; jika dibandingkan dengan responden yang tidak melakukan aktivitas bernyanyi di tempat karaoke (hanya bersosialisasi semata). Demikian juga sebuah review atas banyak penelitian dengan tema aktivitas bernyanyi dan kondisi stres yang dilakukan oleh Gick (2010), yang menghasilkan kesimpulan bahwa melalui aktivitas bernyanyi diperoleh beberapa keuntungan dari dimensi fisik maupun psikis.

Lebih lanjut, review dari beberapa penelitian dengan tema hubungan antara kesehatan, terapi musik, dan aktivitas bernyanyi yang dilakukan oleh Clift et al. (2008). Review tersebut menghasilkan kesimpulan bahwa melalui aktivitas bernyanyi diperoleh beberapa keuntungan, yaitu: terjadi relaksasi kondisi fisik; penurunan emosi dan pengurangan kondisi stres; menimbulkan perasaan bahagia, mood yang lebih positif; menimbulkan perasaan nyaman; peningkatan energi dan daya responsif; meningkatkan tingkat fokus, konsentrasi, serta ingatan; meningkatkan kepercayaan diri dan harga diri.

Aktivitas bernyanyi juga sangat bermanfaat untuk menurunkan tingkat stres yang terkait dengan hubungan interpersonal, seperti penelitian yang dilakukan oleh Davidson \& Almeida (2014). Dari penelitian tersebut diperoleh kesimpulan bahwa melalui aktivitas bernyanyi yang telah dijadwalkan pada program harian pengasuhan terhadap penderita dimensia; mampu mengurangi kondisi stres pada penderita dimensia maupun terhadap pengasuhnya (caregiver).

Berdasarkan pemaparan di atas, dapat ditarik suatu kesimpulan bahwa aktivitas bernyanyi mampu memberikan efek positif terhadap para pelakunya. Namun demikian, selain mampu memberikan efek positif terhadap pelakunya; di sisi lain bahwa aktivitas bernyanyi juga mampu menimbulkan efek negatif, yaitu kondisi stres terhadap pelakunya. Hal tersebut dapat teramati melalui fenomena kontestasi bernyanyi. Seperti penelitian yang telah dilakukan oleh Wesner et al. (1990: dalam Wilson et al., 2002), yang menghasilkan kesimpulan bahwa kecemasan seringkali terjadi ketika seseorang berpenampilan di atas panggung; salah satunya aktivitas bernyanyi.

Dari fakta-fakta tersebut dapat ditarik kesimpulan, bahwa aktivitas bernyanyi bukan hanya mampu mereduksi kondisi stres, namun juga berpeluang untuk menimbulkan kondisi stres terhadap para pelakunya. Berdasarkan pada adanya data empirik tersebut, maka asumsi penelitian ini yaitu bahwa kesiapan pelaku terkait pengusaan elemen-elemen musikal bernyanyi dalam konteks kompetisi bernyanyi memiliki hubungan/relasi dengan kondisi stres para pelakunya. Oleh karena itu, penelitian ini akan dilakukan dengan fokus 
penggalian terhadap kedua variabel tersebut, yaitu elemen-elemen musikal bernyanyi dan kondisi stres pada konteks kompetisi bernyanyi.

\section{Elemen-Elemen Musikal Bernyanyi}

Untuk dapat bernyanyi dengan baik, maka penguasaan elemen-elemen musikal bernyanyi harus dikuasai oleh pelakunya. Elemen-elemen musikal bernyanyi merupakan bagianbagian yang mendasar dan bersifat musikal dari aktivitas bernyanyi. Elemen-elemen musikal bernyanyi tersebut meliputi: berlatih kelenturan suara, pernafasan, perluasan wilayah nada (range), volume suara, mutu suara, artikulasi, resonansi, vibrasi, intonasi, serta ekspresi yang sesuai dengan jiwa lagu yang sedang dinyanyikan.

Tujuan dari berlatih kelenturan suara (fleksibilitas) yaitu, agar organ-organ penunjang produksi suara tidak mengalami kekakuan ketika melafalkan kata-kata tertentu, maupun interval-interval nada-nada tertentu pada saat bernyanyi. Jika hal tersebut tidak dilatih secara baik, maka seorang penyanyi akan mengalami kesulitankesulitan ketika harus menyanyikan suatu lagu yang terkadang memiliki pelafalan yang cepat maupun interval-interval nada yang cukup sulit.

Pernafasan merupakan motor bagi seorang penyanyi. Oleh karena itu prinsip bernafas yang baik untuk aktivitas bernyanyi harus diketahui serta dilatih secara baik pula. Prinsip bernafas dalam aktivitas bernyanyi yaitu, menghirup udara sebanyak mungkin dan mengeluarkannya dengan sehemat mungkin. Secara umum pernafasan dapat digolongkan menjadi tiga: pernafasan dada, pernafasan perut, dan pernafasan diafragma. Dari ketiga pernafasan tersebut, pernafasan difragma lah yang paling ideal untuk aktivitas bernyanyi. Hal tersebut dikarenakan, pernafasan diafragma memiliki kelebihan dibandingkan kedua nafas lainnya yaitu: mampu menciptakan penghirupan nafas dalam kuantitas yang cukup serta mampu untuk menciptakan kestabilan suara dan power/ tenaga yang dapat dikendalikan sesuai dengan kebutuhan.

Perluasan wilayah nada merupakan suatu upaya dari seseorang untuk meningkatkan kemampuan menyanyikan nada yang terendah hingga nada yang tertinggi. Hal tersebut memiliki manfaat ketika seorang penyanyi harus menyanyikan suatu lagu yang memiliki ambitus/ rentang nada yang cukup luas; dengan harapan bahwa nada-nada tersebut dapat dicapai/ dinyanyikan dengan secara baik.

Volume suara merupakan tingkat kekerasan atau kekuatan suara dalam bernyanyi. Hal tersebut secara operasional sangat bergantung pada seberapa banyak atau sedikit udara yang dihembuskan oleh paru-paru untuk menggetarkan pita suara. Seoarang penyanyi yang telah menguasai teknik pernafasan secara baik, ia akan dengan mudah mengendalikan kekerasan setiap suara yang dihasilkannya.

Mutu suara atau kualitas suara pada dasarnya merupakan bawaan yang bersifat alamiah. Namun, seorang penyanyi akan mampu meningkatkan kualitas suaranya dengan memanfaatkan rongga-rongga resonator yang ada pada tubuhnya. Selain untuk meningkatkan kualitas suara, pemanfaatan rongga resonator secara tepat akan membantu dalam hal volume suara.

Artikulasi merupakan bagian yang vital bagi seorang penyanyi. Hal tersebut dikarenakan, bahwa kelebihan dari musik vokal dibandingkan dengan musik instrumental 
yaitu kemampuannya untuk dapat menyampaikan pesan secara akurat kepada pendengarnya. Oleh karena itu, pengartikulasian dari setiap huruf vokal maupun konsonan harus dilakukan secara sempurna.

Vibrasi dapat diartikan sebagai getaran atau gelombang dalam nada sustain. Hal tersebut merupakan suatu hal yang estetis dari kegiatan berolah vokal, namun seorang penyanyi yang baik seharusnya mampu mengendalikan vibrasi pada suaranya. Dengan latihan yang teratur, vibrasi akan muncul secara alami. Sedangkan intonasi merupakan ketepatan seorang penyanyi untuk bersuara sesuai dengan nada yang dikehendaki. Dengan latihan yang teratur seseorang akan semakin peka dan tepat terhadap nada-nada yang harus disuarakan.

Ekspresi dalam bernyanyi merupakan suatu kegiatan yang dilakukan oleh seorang penyanyi terkait dengan bagaimana suatu lagu harus dinyanyikan sesuai dengan jiwa dari lagu tersebut, melalui penggunaan warna suara, dinamika, tempo, serta mimik yang sesuai dan bersinergi. Suatu lagu akan menjadi enak untuk didengar apabila ia dinyanyikan sesuai dengan jiwa lagu tersebut (Prabowo dkk, 1995; Ammer, 1972; Christy, 1961; Budidharma, 2001).

Dari elemen-elemen musikal bernyanyi tersebut di atas, kesemuanya dapat dikelompokkan menjadi tiga aspek, yaitu aspek penguasaan materi lagu, aspek teknis bernyanyi, serta aspek ekspresi. Ketiga aspek tersebut merupakan hal yang harus dikuasai oleh seorang penyanyi, agar dapat bernyanyi secara baik.

\section{Konsep Stres}

Stres merupakan suatu reaksi individu baik bersifat psikis maupun fisik dikarenakan adanya interaksi dengan lingkungnnya. Kondisi stres dapat terjadi jika permintaan eksternal pada diri melebihi sumber daya diri yang ada. Dengan kata lain, bahwa kondisi stres dapat terjadi jika kapasitas sumber daya diri berada di bawah kapasitas tuntutan eksternal yang ada. Indikator-indikator ketika individu sedang dilanda stres yaitu tampak pada dimensi-dimensinya (kognisi, perilaku, emosional, dan fisik); yang menunjukkan peningkatan derajat pada setiap indikatornya (Lazarus; dalam Harrington, 2013).

\section{Metode Penelitian}

Penelitian kualitatif ini akan dilakukan dengan pendekatan studi kasus. Perolehan data dilakukan melalui FGD (Focus Group Discussion: diskusi grup terarah). Analisis data dilakukan melalui pengelompokan data/ mencari pola data (Neuman, 2011). Subjek penelitian ini yaitu, anggota paduan suara Universitas Ahmad Dahlan; PSM UAD Ahda Gitana. Jumlah subjek penelitian (responden) yang dilibatkan pada FGD yaitu 10 (sepuluh) orang. Subjek penelitian memiliki kriteria: mahasiswa S1 dari berbagai fakultas. 


\section{Hasil}

\begin{tabular}{|c|c|}
\hline Dimensi & Hasil/ Indikator \\
\hline $\begin{array}{l}\text { - } \text { Fisik } \\
\text { - } \text { Fisik } \\
\text { - } \text { Fisik } \\
\text { - } \text { Perilaku } \\
\text { - } \text { Kognisik \& } \\
\text { - Kognisi \& } \\
\text { - } \text { Kisik } \\
\text { Kognisi \& } \\
\text { - } \text { Kognik } \\
\text { - Fisik } \\
\text { - Kognisi \& } \\
\text { - } \text { Kisik } \\
\text { - } \text { Fognisik \& } \\
\text { - } \text { Kognisi \& } \\
\text { - Kognisi } \\
\text { - Kognisi } \\
\text { - Kognisi } \\
\text { - Kognisi } \\
\text { - Kognisi }\end{array}$ & $\begin{array}{l}\text { - } \text { Perasaan berdebar-debar } \\
\text { - } \text { Demam panggung } \\
\text { - } \text { Nafas tidak teratur } \\
\text { - } \text { Panik } \\
\text { - } \text { Ketakutan tidak mampu berteknis secara baik dan } \\
\text { - Takut suara bergetar (tidak stabil) } \\
\text { - Khawatir tidak menguasai materi lagu } \\
\text { - Ketakutan sakit perut sebelum berpenampilan } \\
\text { - Khawatir bernyanyi fals (intonasi tidak tepat) } \\
\text { - Khawatir peserta lomba yang lain bisa } \\
\text { - } \text { terpenampilan secara lebih baik } \\
\text { - } \text { menjelang berpenampilan } \\
\text { - Takut berpenampilan yang lebih buruk daripada } \\
\text { - } \text { kroses latihan } \\
\text { - Takut mental menjadi down } \\
\text { - Khawatir dengan ruang yang baru untuk } \\
\text { - } \text { kerpenampilan } \\
\text { (audiens) }\end{array}$ \\
\hline
\end{tabular}

Pada tabel 1 di atas menunjukkan adanya kekhawatiran-kekhawatiran akan ketidakmampuan terlaksananya aktivitas bernyanyi secara baik dalam konteks kompetisi bernyanyi. Hal tersebut dapat diartikan sebagai kurang terkuasainya elemen-elemen musikal bernyanyi yang diantaranya: kekhawatiran aspek teknis bernyanyi, aspek penguasaan materi lagu, serta aspek ekspresi.

Suatu keadaan kondisi stres juga tampak sedang dialami oleh para pelaku. Hal tersebut dapat terkonfirmasi melalui adanya indikator-indikator dari setiap dimensinya yang menunjukkan derajat peningkatannya. Dengan kata lain, indikator-indikator stres muncul pada setiap dimensinya.

\section{Analisis}

Untuk menganalisis data yang telah diperoleh melalui FDG, maka langkah pertama yang harus dilakukan yaitu dengan cara pengelompokan data/mencari pola data terlebih dahulu. Dari pengelompokan data-data tersebut, maka analisis dari setiap variabelnya diperoleh sebagai berikut. 


\section{Variabel Elemen-Elemen Musikal Bernyanyi}

Dari hasil perolehan data melalui FGD pada tabel 1, diperoleh data-data empirik yang terkait dengan elemen-elemen musikal bernyanyi para pelakunya. Dari data tersebut dapat disimpulkan bahwa para pelaku/ penyanyi belum menguasai elemen-elemen musikal bernyanyi yang dibutuhkan. Hal tersebut dapat teridentifikasi dari adanya kekhawatiran akan aspek penguasaan materi lagu, aspek teknis bernyanyi, aspek ekspresi.

\section{Variabel Kondisi Stres Pada Konteks Kompetisi Bernyanyi}

Berdasarkan tabel rangkuman hasil FGD di atas, maka data yang diperoleh dapat dikelompokkan menjadi 4 (empat) bagian dimensi. Dimensi tersebut terdiri dari dimensi fisik, dimensi perilaku, dimensi kognisi \& fisik, dan dimensi kognisi.

Keempat bagian dimensi tersebut menunjukkan adanya peningkatan indikator pada setiap dimensinya. Peningkatan indikator tersebut bergerak linier dengan arah favorable dari konsep stres. Artinya, bahwa adanya peningkatan indikator menunjukkan adanya kondisi stres yang sedang dialami oleh subjek penelitian. Pada dimensi fisik tampak adanya 3 (tiga) indikator yang teramati yaitu : perasaan berdebar-debar, demam panggung, nafas tidak teratur. Hal tersebut mengartikan adanya kondisi stres yang dapat dirasakan oleh subjek penelitian melalui dimensi fisiknya.

Pada dimensi perilaku tampak adanya 1 (satu) indikator yang teramati yaitu, panik. Hal tersebut mengartikan adanya kondisi stres yang dirasakan oleh subjek penelitian melalui dimensi perilakunya. Pada dimensi kognisi \& fisik tampak adanya 7 (tujuh) indikator yang teramati yaitu: ketakutan tidak mampu berteknis bernyanyi secara baik dan benar, ketakutan suara yang bergetar/tidak stabil untuk bernyanyi, kekhawatiran tidak menguasai materi lagu yang akan/sedang dinyanyikan, ketakutan sakit perut sebelum berpenampilan, khawatir bernyanyi fals/intonasi tidak tepat, khawatir peserta lomba yang lain bisa berpenampilan secara lebih baik, takut kondisi fisik menjadi sakit menjelang berpenampilan. Hal tersebut mengartikan adanya kondisi stres yang dirasakan oleh subjek penelitian melalui dimensi kognisi \& fisik.

Pada dimensi kognisi tampak adanya 6 (enam) indikator yang teramati yaitu: cemas, takut berpenampilan lebih buruk daripada proses latihan, khawatir suara tidak bisa keluar, takut mental menjadi down, khawatir dengan ruang yang baru untuk berpenampilan, khawatir dan cemas terhadap para penonton (audiens). Hal tersebut mengartikan adanya kondisi stres yang dirasakan oleh subjek penelitian melalui dimensi kognisinya.

Berdasarkan indikator pada keempat dimensi tersebut, yaitu kesemua indikator menunjukkan pola yang sama menuju ke arah kondisi stres; maka dapat ditarik kesimpulan bahwa subjek penelitian mengalami peningkatan kondisi stres ketika dihadapkan pada aktivitas bernyanyi pada konteks kompetisi bernyanyi.

\section{Pembahasan}

Aktivitas bernyanyi dalam konteks kontestasi/kompetisi bernyanyi, ternyata mampu membuka peluang bagi seseorang untuk dilanda kondisi stres. Hal tersebut memberikan 
gambaran kenyataan yang lain dari penelitian-penelitian ilmiah maupun asumsi masyarakat yang menyatakan bahwa aktivitas bernyanyi maupun berkaraoke mampu menjadi suatu media dalam rangka mereduksi kondisi stres yang sedang dirasakan.

Berdasarkan hasil FGD tersebut, dapat teramati bahwa semua indikator dari setiap dimensi menunjukkan gejala-gejala kondisi psikis seseorang yang sedang dilanda stres. Hal tersebut mengartikan bahwa ketika seseorang bernyanyi dalam konteks kompetisi bernyanyi; di luar kepentingan pengekspresian diri semata maupun sekedar senangsenang; akan membuka peluang untuk terciptanya kondisi stres bagi pelakunya. Salah satu alasan yang dapat menjelaskan hal tersebut dapat terjadi yaitu, adanya permintaan maupun tuntutan terhadap diri yaitu untuk bernyanyi secara baik dan benar, dengan harapan dapat memberikan penampilan terbaiknya sehingga kemenangan berdasarkan prestasi yang baik dapat tercapai.

Dengan adanya tuntutan eksternal tersebut, maka terbukalah kemungkinan bagi para pelaku untuk dilanda kondisi stres. Berdasarkan konsep stres, kondisi stres tidak akan terjadi jika sumber daya diri lebih besar dari tuntutan eksternal pada diri. Dengan demikian hanya ada dua kemungkinan pilihan yang akan terjadi pada diri pelaku aktivitas bernyanyi dalam konteks kompetisi bernyanyi. Pertama, para pelaku tidak akan stres asalkan mereka memiliki sumber daya diri yang lebih besar dari tuntutan eksternal; artinya, mereka harus menguasai elemen-elemen musikal bernyanyi secara baik yang meliputi penguasaan aspek materi lagu, aspek teknis bernyanyi, aspek ekspresi. Kedua, para pelaku akan dilanda kondisi stres jika mereka tidak memiliki sumber daya diri yang lebih besar dari tuntutan ekternal; artinya mereka tidak menguasai elemen-elemen musikal bernyanyi yang dibutuhkan secara baik.

Berdasarkan data hasil FGD, maka dapat diperoleh beberapa poin yang akan memberikan penjelasan mengapa kondisi stres bisa terjadi pada individu yang melakukan aktivitas bernyanyi dalam konteks kompetisi bernyanyi. Di bawah ini disajikan tabel yang menyatakan hubungan antara hasil FGD/ indikator kondisi stres responden terhadap dimensi eleman musikal bernyanyi.

\begin{tabular}{|c|c|}
\hline Hasil FGD/ Indikator & $\begin{array}{c}\text { Dimensi Elemen Musikal } \\
\text { Bernyanyi }\end{array}$ \\
\hline $\begin{array}{l}\text { - } \\
\text { - Ketakutan tidak mampu berteknis secara } \\
\text { baik dan benar. } \\
\text { - } \quad \text { Takut suara bergetar (tidak stabil). } \\
\text { - Khawatir tidak menguasai materi lagu. } \\
\text { - Khawatir bernyanyi fals (intonasi tidak } \\
\text { tepat). } \\
\text { - Takut kondisi fisik menjadi sakit ketika } \\
\text { - } \text { Kenjelang berpenampilan. } \\
\text { - } \text { berpenampilan. } \\
\text { - } \text { Takut berpenampilan yang lebih buruk } \\
\text { - Khawatir peserta lomba yang lain bisa } \\
\text { berpenampilan secara lebih baik. } \\
\text { - Khawatir suara tidak bisa keluar. }\end{array}$ & 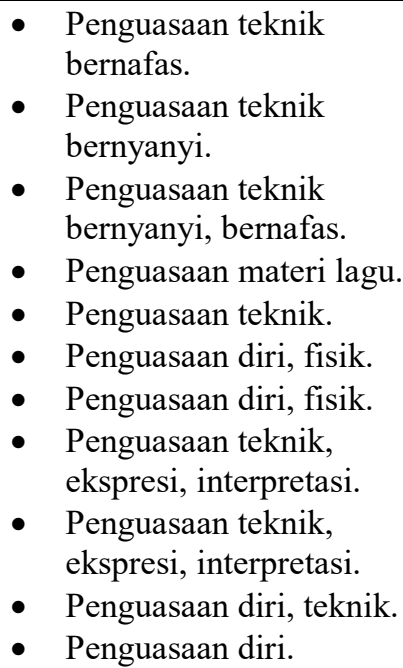 \\
\hline
\end{tabular}


- Perasaan berdebar-debar.

- Demam panggung.

- Panik.

- Cemas.

- Takut mental menjadi down.

- Khawatir dengan ruang yang baru untuk berpenampilan.

- Khawatir dan cemas terhadap para penonton (audiens)
- Penguasaan diri.

- Penguasaan diri.

- Penguasaan diri.

- Penguasaan diri.

- Penguasaan diri.

- Penguasaan diri.

Tabel 2

Hubungan antara indikator stres terhadap dimensi elemen musikal bernyanyi

Dari tabel 2 di atas, maka tampak bahwa aktivitas bernyanyi dalam konteks kompetisi bernyanyi mampu menyebabkan kondisi stres; hal tersebut dikarenakan tuntutan eksternal yang tidak dapat diimbangi dengan sumber daya diri yaitu, penguasaan elemen-elemen musikal bernyanyi secara baik. Kolom pertama: hasil FGD/ indikator, yang muncul ketika ketidaksiapan terhadap penguasaan yang terkait dengan sumber daya diri personal, sehingga menyebabkan indikator stres. Kolom kedua : dimensi elemen musikal bernyanyi yang belum ataupun tidak terkuasai secara baik.

Berdasarkan tabel 2 tersebut, diperoleh suatu hubungan yang jelas; bahwa kondisi stres (pada kolom 1) tersebut terjadi dikarenakan adanya ketidaksiapan (pada kolom 2). Dengan kata lain, bahwa kondisi stres tersebut tercipta dikarenakan adanya tuntutan untuk bernyanyi secara baik dan benar yang belum dapat terpenuhi. Secara terperinci: perasaan berdebar, demam panggung, panik, cemas, takut mental menjadi down, khawatir dengan ruang yang baru untuk berpenampilan, khawatir dan cemas terhadap para penonton (audiens); disebabkan oleh ketidaksiapan seorang penyanyi terkait dengan penguasaan dirinya. Penguasaan diri dalam konteks bernyanyi pada kompetisi dapat diartikan sebagai seberapa mampukah seseorang mengatasi kondisi yang sedang terjadi ketika sedang atau akan berpenampilan. Penguasaan diri ketika berpenampilan sangat dibutuhkan ketika seseorang harus berpenampilan di depan umum/ di depan banyak orang; biasanya selalu dibutuhkan ketika terkait dengan phobia sosial.

Khawatir suara tidak bisa keluar saat berpenampilan, disebabkan oleh ketidaksiapan seorang penyanyi terkait dengan penguasaan diri dan teknik bernyanyinya. Takut berpenampilan lebih buruk daripada proses latihan, khawatir peserta lomba yang lain mampu berpenampilan secara lebih baik; disebabkan oleh ketidaksiapan seorang penyanyi terkait dengan penguasaan teknik, ekspresi dan interpretasi. Takut akan kondisi fisik menjadi sakit ketika menjelang berpenampilan, ketakutan akan sakit perut sebelum berpenampilan; disebabkan oleh ketidaksiapan seorang penyanyi terkait dengan penguasaan diri dan fisik.

Khawatir bernyanyi fals/ intonasi yang tidak tepat, disebabkan oleh ketidaksiapan seorang penyanyi terkait dengan penguasaan teknis bernyanyi. Khawatir tidak menguasai materi lagu saat berpenampilan, disebabkan oleh ketidaksiapan seorang penyanyi terkait dengan penguasaan materi lagu (belum hafal lirik lagu atau maupun melodi lagu) yang akan dinyanyikan. Takut suara bergetar atau tidak stabil saat berpenampilan, disebabkan 
oleh ketidaksiapan seorang penyanyi terkait dengan penguasaan teknik bernyanyi dan pernafasan secara benar. Nafas yang tidak teratur, disebabkan oleh ketidaksiapan seorang penyanyi terkait dengan penguasaan teknik bernafas secara benar. Ketakutan tidak mampu berteknis secara baik dan benar ketika berpenampilan, disebabkan oleh ketidaksiapan seorang penyanyi terkait dengan penguasaan teknik bernyanyi secara baik dan benar.

\section{Kesimpulan}

Aktivitas bernyanyi dalam konteks kompetisi bernyanyi akan sangat membuka peluang untuk terciptanya kondisi stres bagi para pelakunya. Hal tersebut sangat bergantung dari kemampuan diri para pelaku yang terkait dengan sumber daya diri yang dimiliki untuk mengimbangi maupun menjawab tuntutan eksternal yang menghampiri diri. Apabila tuntutan yang ada dapat diimbangi dengan sumber daya diri, maka kondisi stres tidak akan mendera. Namun, jika sumber daya diri tidak dapat mengimbangi tuntutan ekternal yang menghampiri diri, maka kondisi stres akan mendera individu tersebut.

Dari hasil penelitian ini, dapat ditarik kesimpulan bahwa para pelaku aktivitas bernyanyi (responden) dalam konteks kompetisi bernyanyi tidak memiliki kesiapan yang terkait dengan penguasaan elemen-elemen musikal bernyanyi yang dibutuhkan untuk bernyanyi secara baik; sehingga hal tersebut mampu menciptakan kondisi stres terhadap para pelakunya. Ketidaksiapan aspek penguasaan materi lagu, aspek teknis bernyanyi, serta aspek ekspresi yang dibutuhkan untuk bernyanyi secara baik; membuat para pelaku mengalami kesulitan-kesulitan untuk bernyanyi secara baik, yang kemudian hal tersebut dianggapnya sebagai hal yang bersifat tuntutan yang tidak dapat terselesaikan sehingga menyebabkan kenyamanan diri terusik.

Berdasarkan hasil dari penelitian ini, maka aktivitas bernyanyi yang dilakukan dalam konteks kompetisi bernyanyi seharusnya dilakukan dengan tanpa kondisi stres. Hal tersebut menjadi penting, karena jika seseorang dilanda kondisi stres, maka kinerja dari organ-organ penunjang produksi suara tidak akan berkerja secara baik; sehingga suara yang akan dihasikannya pun akan kurang baik. Oleh karena itu, sangat disarankan bagi siapapun yang bernyanyi dengan tujuan kompetisi bernyanyi; seharusnya menguasai elemen-elemen musikal bernyanyi yang dibutuhkan. Penguasaan aspek materi lagu, aspek teknis bernyanyi, serta aspek ekspresi merupakan modal sumber daya diri untuk menjawab tuntutan ekternal pada diri, yaitu bernyanyi secara baik.

\section{KEPUSTAKAAN}

Ammer, Christine. (1972). Harper's Dictionary of Music. Barnes and Noble Books. London.

Badudu, J.S. \& Sutan M.Z. (2001). Kamus Umum Bahasa Indonesia. Pustaka Sinar Harapan. Jakarta.

Budidharma, Pra. (2001). Metode Vokal Profesional. Gramedia. Jakarta.

Caesari, Edgar F. Herbert. (1958). The Science and Sensations of Vocal Tone: A School of Natural Vocal Mechanism. J.M. Dent and Son Ltd. London. 
Tio Roby, RELASI PENGUASAAN ELEMEN-ELEMEN MUSIKAL BERNYANYI DAN KONDISI STRES ...

Clift, Stephen; Grenville Hancox; Rosalia Staricoff and Christine Whitmore. (2008). Singing and Health: Summary of a Systematic Mapping and Review of Non-Clinical Research: Sydney De Haan Research Centre for Arts and Health. Canterbury Christ Church University.

Davidson, Jane W. \& Renita A. Almeida. (2014). Journal: “An Exploratory Study of The Impact of Group Singing Activities on Lucidity, Energy, Focus, Mood, and Relaxation for Persons With Dementia and Their Caregivers". Springer.

Gick, Mary L. (2010). Singing, Health, and Well-Being: A Health Psychologist's Review. Carleton University.

Harrington, Rick. (2013). Stress, Health, and Well-Being: Thriving in $21^{\text {st }}$ Century. MPS Limited, a Macmillan Company. America.

Matsumoto, Junko; Shiori Aoki; Manami Watanabe. Journal: "Positive Psychological and Interpersonal Effects by Karaoke”. Jepang.

Prabowo, Aris Herning, dkk. (1995). Seni Musik I. PT Pabelan. Surakarta.

Wilson, Glenn D. \& David Ronald. (2002). "Performance Anxiety" (The Science \& Psychology of Music Performance: Creative Strategies for Teaching and Learning: Richard P. Gary E. McPherson). Oxford University Press. New York.

\section{Nara sumber :}

Anggota Paduan Suara Mahasiswa (PSM) Universitas Ahmad Dahlan Yogyakarta. 